\title{
IMPORTANCE OF RESEARCH TO GAIN KNOWLEDGE IN HEALTH STUDENTS
}

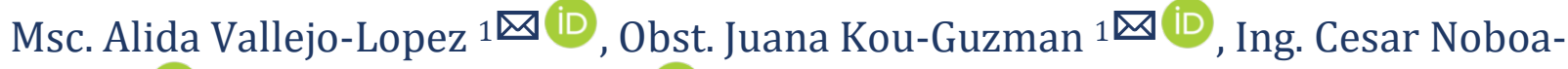 \\ Teran ${ }^{1}$ iD, Dra. Ana-Maria Viteri 1 iD \\ ${ }^{1}$ Facultad De Ciencias Medicas Universidad De Guayaquil- Ecuador
}

DOI: https://doi.org/10.29121/granthaalayah.v8.i8.2020.864

Article Type: Research Article

Article Citation: Msc. Alida VallejoLopez, Obst. Juana Kou-Guzman, Ing. Cesar Noboa-Teran, and Dra. AnaMaria Viteri. (2020). IMPORTANCE OF RESEARCH TO GAIN KNOWLEDGE. IN HEALTH STUDENTS. International Journal of Research -GRANTHAALAYAH, 8(8), 37-41.

https://doi.org/10.29121/granthaa layah.v8.i8.2020.864

Received Date: 26 July 2020

Accepted Date: 19 August 2020

Keywords:

Research

Knowledge

Health

\section{ABSTRACT}

Research in the teaching-learning process in Higher Education Institutions is very useful to understand the issues that refer to society and the world around us. Schools should foster researchers' interest in science, as well as prepare them to envision the various applications and responsibilities of a researcher. This mission must be fulfilled from the first years of study, in all areas of knowledge, especially in the area of health. The development of scientific activity must adapt to the changes imposed by scientific, technological and innovation development. Several factors influence this process that must be analyzed. Research is considered the basis for obtaining knowledge, which will allow us to understand and find solutions to the life and health problems of the population.

\section{INTRODUCTION}

Research is an activity aimed at obtaining significant findings that increase human knowledge and enrich science, it is considered a useful tool in the search for knowledge, and it arises from man's curiosity, from its origin, generating changes in the world through throughout history.

The word investigate comes from the Latin investigare derived from vestigiun which means to go in search of a clue. (Universia México 2016) means searching and discovering, in order to elaborate new theories in different disciplines or modify existing ones.

Research and science are linked in a decisive way to understand the world around us and the complex processes that take place in it. Being an inherent quality of man, it has a strategic role in the development of a nation, it is very useful in all areas of knowledge and in the social, economic, scientific, academic, and health fields.

When talking about research, it is thought that this activity can only be carried out by a formal researcher, such as a scientist, a specialist, a doctor or a physicist, limiting the wide field of research, forgetting that each person is a thinking being, that every day he is curious about something.

(C) 2020 The Author(s). This is an open access article distributed under the terms of the Creative Commons Attribution License, which permits unrestricted use, distribution, and reproduction in any medium, provided the original author and source are credited. 
The reality is that in the curiosity of man an investigation is born, and with it an informal researcher is born, that is, every time I look for information on a topic, I am investigating and expanding my knowledge, that is research. This situation in many cases goes unnoticed by the common man, but it reveals the great capacity of researchers that everyone has.

Taking into account this antecedent, it can be said that this activity: Has the ability to promote the development of skills and the discovery of new facts, in accordance with advances in technique, technology and thought (Bijarro, Francisco 2007).

In this context, all human beings have the ability to investigate, but not everyone is interested, although man is an innate researcher, due to his natural curiosity, each person must develop it.

Since Wilhelm Von Humboldt added research units to the university process, the value of the institutional mission of the University has increased, to generate new knowledge, to transcend and not remain stuck in theories considered as absolute truths. (Deiters, H. 1960). With his great contribution to the university, he began to do science.

The relationship between teaching and research since the formation of modern European universities during the 19th century was the basis of the German university tradition; while that of the separation of both processes was the foundation of the Napoleonic University (Medina, D. E. M., \& Morales, N. A. 2014)

These antecedents marked the evolution of the universities by promoting that the new scientific knowledge, creative ideas and technologies generated within the university, are put at the service of society, are transformed into new valuable products or services for the market and therefore, generate wealth and social welfare (Molina, Ó. D. 2015)

The training of researchers in education in Latin America is preceded by the development of disciplinary fields that address education as their object of study and by the presence of neoliberal educational models. In addition, the production of educational knowledge has to face the challenges of great changes in science, technology and society. (Rincón, C. 2011).

Research has no limits, because each new known topic may be the one that generates a new question, a new topic to understand and therefore a new investigation.

To respond to the requirements of higher education in the 21st century, essential transformations are required aimed at improving the educational model - in order to respond effectively and appropriately to the demands of this new context that evolves day by day in today's world. (Gómez, J; Diéguez, P.; Gómez 2014)

Although, in the performance of teaching work, there is generally the view that learning should be considered only from a disciplinary perspective and in many cases comprehensive learning that includes research to strengthen people's knowledge is neglected.

\section{CURRENT VISION}

In the scenario of the new century, professionals in the medical area must be prepared to face new global challenges, among them the recognition of health problems and diseases that are still in force and new pathologies that affect people's health, because they are more worried that never the great responsibility of finding solutions that can save the lives of the population.

This mission must be assumed with responsibility, discipline and academic rigor, to implement them a committed and dedicated faculty is needed.

In the health area, the Medicine career and its related careers have the obligation to know the relevant topics for the area, so teaching should be considered considering the most relevant content and research should be the component that complements this learning. The student should not be a data bank, but a restless being, capable of questioning and solving problems (Norero V., Colomba. 2000)

Research plays an important role in academic training to improve learning processes in university students. All existing knowledge is the result of research, and new discoveries are produced every day that contribute to various areas of daily life.

The development of investigative competences allows expanding the field of knowledge. Generate interest in topics that are attractive to each student and then support them with tools that facilitate their access to sources of information such as reliable databases. 


\section{Msc. Alida Vallejo-Lopez, Obst. Juana Kou-Guzman, Ing. Cesar Noboa-Teran, and Dra. Ana-Maria Viteri}

It is not about telling them what to investigate but about opening the door to a world of information, so that they can analyze it.

The university is the most suitable place to promote scientific activity. In this way, it makes it possible to enrich production systems, obtain updated information and attract financial resources, as well as establish scientific projects with greater risk and potential return. (Norero V., Colomba. 2000)

Institutions must support not only theoretical academic training, but also the training and understanding of basic concepts of science and statistics, a mechanism through which the relevance of a medical or scientific study is presented or established, regardless of the field in which it is carried out, perform developed. ((Ruiz Juan Carlos, M.)

Another fundamental factor is the way the manuscript is written, using the language correctly and explaining the ideas in logical and coherent paragraphs. All research must look for antecedents, foundations, concepts, but also the interpretation and the way to relate all the information is the contribution of the authors.

The range of knowledge that can be covered with research work and practical activities in class is very wide. But before doing so, the student must be guided about the rules, which are applied in the process, for this, first, the basic elements of an investigation must be informed, the order, the extension, the organization, the process, information, bibliographic citations, etc.

In the new context of education: The teacher must promote the practice of research, since the best way to learn is experience, it is not enough to know formulas, the experience will be made by the researcher, as long as this path is not available, it will only continue to be a repetitive teacher of experiences foreign. "For this reason, the university professor is not a professor, nor the student an apprentice, but someone who investigates by himself, guided and guided by the professor. (Juárez R. Alejandro 2011.)

In academic training, various strategies can be used to promote research skills, the same ones that are chosen by teachers. To carry out a scientific investigation, the student has to learn that it starts from a new idea, it is structured as a hypothesis, which is accepted or rejected based on the results and culminates with its publication (González Argotea Javier 1995)

Routine class activities can be enriched with activities that engage students. Among the many activities that can be carried out are various strategies such as PBL problem-based learning, or ABI inquiry-based learning, which can be applied in groups for greater participation with input from each member. Research-Based Learning (ABI) consists of the application of teaching and learning strategies that have the purpose of connecting research with teaching, allowing the partial or total incorporation of the student in research based on scientific methods, under the teacher supervision. It refers to the design of the academic program where students are required to make intellectual and practical connections between the content and skills declared in the program, the research approaches and the limits of the disciplines that compose it. (Tecnológico de Monterrey, 2014)

In academic training, the time the student dedicates to research depends on motivation and that is the engine that generates their performance. You have to have an open mind to reveal those details that have been ignored by other researchers (Vallejo A. et al 2020).

In the area of health, the career of Medicine and its related careers, have the obligation to know issues relevant to the area, therefore, teaching must be raised considering the most relevant content and research must be the component that complements that learning. The student should not be a data bank, but a restless being, capable of questioning and solving problems (Norero V., Colomba. 2000)

Many students entering medical careers in developing countries are unaware of the importance of research.

This vision in many cases is not shared by all teaching staff, since it has been observed more than once that teachers do not allow students to develop their interest in learning about topics that are not implicit in the study programs, and repress the development of possible researchers since its inception.

In the field of the university educational community, research work will always be productive for all those involved. It is urgent, then, to promote research as a resource for the autonomous production of knowledge, which depends not only on the creation of individual and group expertise and learning, but also on the efficient management and organization of investigative processes (Padrón, J 2007)

Education, science and research are the bases that sustain the development of knowledge. What would the world be like if people didn't investigate? And in the medical area it is even more important to promote research. How can you find medicines to alleviate illnesses? How would you understand the virus development process? There are so many questions that would not have an answer if researchers are not supported, that is why research is so important and it is imperative to generate a culture of new researchers, who assume their role, with a vision of the future. Raise awareness that to protect the life, health and survival of man on the planet, it is necessary to investigate. 
Higher education institutions, within their ordinary activities, include research, even when the university is more than teaching, since currently there can be no university where research is not done. Universities must impact, leave a mark in a region or country, beyond graduates, and one way to do this is through research. (Mazuera Arias, R. 2016).

\section{CONCLUSIONS}

Research is the basis of new knowledge, it exists through restless minds, who question every day everything that exists in the world we inhabit and also what exists outside of it.

Higher Education Institutions have the duty to promote academic growth in the teaching-learning process and one way to achieve this is to promote interest in research in all areas of knowledge.

The education of the new century has the great social responsibility of training competent professionals and honest researchers, using appropriate strategies for this purpose, because it constitutes the fundamental integral basis of the professional training process.

For a country to grow in knowledge it must have solid foundations that serve as fundamental pillars of knowledge in the area of health. This mission must be assumed with responsibility, discipline and academic rigor. To implement them, ethical teachers are needed and committed to their profession.

\section{SOURCES OF FUNDING}

This research received no specific grant from any funding agency in the public, commercial, or not-for-profit sectors.

\section{CONFLICT OF INTEREST}

The author have declared that no competing interests exist.

\section{ACKNOWLEDGMENT}

None.

\section{REFERENCES}

[1] Bijarro, Francisco (2007): "Desarrollo estratégico para la investigación científica", Cancún, <www.eumed.net/libros-gratis/2007c/306/306.zip> [15/08/2016].

[2] Universia México. (2016). La importancia de la investigación en las tareas universitarias. Recuperado de https://noticias.universia.net.mx/cultura/noticia/2016/11/04/1145206/importancia-investigaciontareas-universitarias.html

[3] Castillo Vargas Andrés Dr. Importancia de la divulgación en la comunicación científica académica Instituto de Investigaciones Psicológicas Escuela de Psicología Universidad de Costa Rica http://www.ebci.ucr.ac.cr/sites/default/files/descargables/castillo_vargas_andres_importancia_de_la_divul gacion_en_la_comunicacion_cientifica_academica.pdf

[4] Mazuera Arias, Rina, La investigación y las revistas científicas. Revista Virtual Universidad Católica del Norte [en linea] 2016, (Febrero-Mayo) : [Fecha de consulta: 8 de agosto de 2019] Disponible en:<http://qwww.redalyc.org/articulo.oa?id=194244221001> ISSN 0124-5821

[5] González Argotea Javier, Alexis Alejandro García-Rivero B y Alberto Juan Dorta-Contreras Articulo Original Producción Científica Estudiantil en Revistas Médicas Cubanas 1995-2014. Universidad Nacional Autónoma de México, Facultad de Medicina Disponible en Internet 2 de marzo de 2016 Inv Ed. Med.2016;5(19):155--163 file:///c:/Users/uf/Downloads/s2007505716000247 S300 es.pdf

[6] GOMEZ, J. ; DIEGUEZ, P.; GOMEZ 2014 Motivando el interés por la investigación científica en estudiantes de educación media superior Congreso Iberoamericano de Ciencia, Tecnología, Innovación y Educación D ISBN: 
978-84-7666-210-6 - Artículo 353 Buenos Aires Argentina Benemérita Universidad Autónoma de Puebla. México. file:///C:/Users/uf/Downloads/353.pdf

[7] Medina, D. E. M., \& Morales, N. A. (2014). Importancia del cambio generacional para el desarrollo de la ciencia y la tecnología en México. Hitos de ciencias económico administrativas, (50), 35-40.

[8] Molina, Ó. D. (2015). La transferencia de conocimiento científico y tecnológico: un reto que deben afrontar las universidades. Portal de la Ciencia, 8, 9-15.

[9] Norero V., Colomba. (2000). Medicina y ciencia: una relación indispensable. Revista chilena de pediatría, 71(2), 81-82. https://dx.doi.org/10.4067/S0370-41062000000200001 https://scielo.conicyt.cl/scielo.php?script=sci_arttext\&pid=S0370-41062000000200001

[10] Rincón Ramírez Carlos LA FORMACIÓN DE INVESTIGADORES EN EDUCACIÓN: RETOS Y PERSPECTIVAS PARA AMÉRICA LATINA EN EL SIGLO XXI Universidad Autónoma de Chiapas, Revista Iberoamericana de Educación (ISSN: 1681-5653) México file:///C:/Users/uf/Downloads/595Rincon.pdf

[11] Norero V., Colomba. (2000). Medicina y ciencia: una relación indispensable. Revista chilena de pediatría, 71(2), 81-82. https://dx.doi.org/10.4067/S0370-41062000000200001 https://scielo.conicyt.cl/scielo.php?script=sci_arttext\&pid=S0370-41062000000200001

[12] Tecnológico de Monterrey, 2014 http://sitios.itesm.mx/va/diie/tecnicasdidacticas/7_1.htm http://sitios.itesm.mx/va/dide2/tecnicas_didacticas/abi/qes.htm

[13] Morales, P. (2010). INVESTIGACIÓN E INNOVACIÓN EDUCATIVA. REICE. Revista Iberoamericana sobre Calidad, Eficacia y Cambio en Educación, 8 (2), 47-73. https://www.redalyc.org/pdf/551/55114080004.pdf

[14] Padrón, J. 2007. Tendencias Epistemológicas de la Investigación Científica en el Siglo XXI Cinta de Moebio 28: 1-28 http://www.facso.uchile.cl/publicaciones/moebio/28/padron.pdf

[15] Ruiz Juan Carlos, M. (s.f.). LA INVESTIGACIÓN CIENTÍFICA EN EL ECUADOR. Medicina Crítica, II (2). Obtenido de http://www.medicosecuador.com/medicina_critica/rev_vol2_num2/la_investigaciona.html

[16] Vallejo López, A. (2020). El papel del docente universitario en la formación de estudiantes investigadores desde la etapa inicial. Educación Médica Superior, 34(2). Recuperado de http://www.ems.sld.cu/index.php/ems/article/view/1579 